\title{
PENERAPAN MODEL PEMBELAJARAN COOPERATIVE LEARNING TIPE STAD \\ UNTUK MENINGKATKAN KEMAMPUAN MEMBACA PEMAHAMAN BAHASA INGGRIS
}

\author{
THE IMPLEMENTATION OF STUDENT TEAMS-ACHIEVEMENT DIVISIONS \\ (STAD) TYPE OF COOPERATIVE LEARNING ENCHANCHING STUDENTS' \\ READING COMPREHENSION
}

\author{
Firdaus \\ Guru Sekolah Dasar Negeri 001 Rambah Rokan Hulu Riau \\ E-mail : firdaus_muhammad79@yahoo.com
}

\begin{abstract}
ABSTRAK
Penelitian ini bertujuan untuk mengetahui efektivitas penerapan model pembelajaran cooperative learning tipe Student Teams-Achievement Divisions (STAD) dalam pembelajaran Bahasa Inggris untuk meningkatkan kemampuan membaca pemahaman peserta didik. Studi ini melibatkan peserta didik SMP Negeri I Minas kelas VIII6 sebagai kelas eksperimen dan VIII-7 sebagai kelas kontrol di Kabupaten Siak tahun pelajaran 2016/2017. Teknik pengumpulan data berupa tes membaca pemahaman, angket dan observasi. Hasil uji hipotesis dapat disimpulkan bahwa penerapan model pembelajaran cooperative learning tipe STAD secara signifikan dapat meningkatkan keterampilan membaca pemahaman pada pembelajaran Bahasa Inggris.
\end{abstract}

Kata kunci: cooperative learning, STAD, kemampuan membaca pemahaman

\section{ABSTRACT}

This research aims to study the effectiveness of Student Teams-Achievement Divisions (STAD) type of cooperative learning in increasing students 'reading comprehension. This study involves SMP Negeri I Minasstudents of grade VIII-6 as experimental group and VIII-7 as control group in Siak District in 2016/2017. Collecting data techniques include of reading comprehension test, questionaire and observation. The conclusion of research finding is that the implementation of cooperative learning of STAD type can increase students' reading comprehension significantly compared to conventional learning model.

Keyword: STAD, reading comprehension

\section{PENDAHULUAN}

Membacapemahamantelah didefinisikan oleh para ahli linguistik secara beragam. Caldwell (2016:4) mengatakan bahwa membaca pemahaman adalah proses mengekstrak dan merekonstruksi makna secara simultan melalui interaksi dan keterlibatan dengan bahasa tulisan. Pengertian ini mengandung arti bahwa pemahaman terjadi ketika seseorang membaca teks kemudian dia mampu memperoleh informasi yang diperlukan dari teks tersebut. Sebagaimana dikemukakan oleh Lems, Miller, \& Soro (2014:170) bahwa membaca pemahaman merupakan kemampuan menyerap makna dari teks yang disajikan. Membaca pemahaman bukan kemampuan statis tetapi kemampuan yang beragam sesuai dengan tujuan membaca dan teks yang dibaca. Kegiatan ini akan melibatkan interaksi antara teks dengan latar belakang pengetahuan pembaca jika keterampilan prasyaratnya dipenuhi, seperti penguasaan kosa kata, tata bahasa dan kemampuan kognitif lainnya. Pendapat Lems, Miller dan Soro tersebut didukung oleh Wooley dalam Qismullah Yusuf, Natsir, \& Hanum BEd, (2015:100-101) yang mengatakan bahwa membaca pemahaman merupakan proses pembentukan makna dari teks; oleh sebab itu kegiatan ini bertujuan memperoleh pemahaman yang menyeluruh dari yang digambarkan dalam teks dibanding dengan memaknai kata atau kalimat tersirat. Oleh karena itu, keterampilan ini bisa dikatakan sebagai usaha untuk memahami teks, memperluas pengetahuan dan informasi 
pembaca. Tujuan intinya adalah memahami isi pesan dalam teks tertulis.

Membaca pemahaman merupakan salah satu kemampuan yang sangat krusial untuk dimiliki peserta didik. Kemampuan ini membantu mereka mengetahui dan memahami aspek-aspek kebahasaan lain dengan baik, seperti kosa kata, tata bahasa dan pesan yang disampaikan dalam wacana. Selain itu, kemampuan membaca ini bisa digunakan dalam berbagai bidang disiplin ilmu, tidak hanya dalam pembelajaran bahasa Inggris saja. Terkait bahasa Inggris di Indonesia sebagai bahasa asing (English as Foreign Language/EFL), maka kemampuan membaca peserta didik itu ditekankan pada membaca pemahaman (reading comprehension) yang difokuskan pada pemahaman berbagai jenis teks. Lebih lanjut, Jeffries, Mikulecky, \& Mikulecky (2012:1) menjelaskan alasan-alasan mengapa membaca dalam bahasa Inggris itu penting. “...memperkaya kosa kata bahasa Inggris, memperbaiki kualitas kemampuan menulis bahasa Inggris, ..., membaca merupakan cara terbaik untuk menggali ide-ide, fakta-fakta dan pengalaman-pengalaman yang baru." Sampai di sini, jelaslah bahwa kemampuan membaca sangat penting peranannya bagi keberhasilan belajar peserta didik dalam bahasa Inggris.

Kehadiran pembelajaran membaca pemahaman yang terencana dengan baik dan diimplementasikan dengan baik pula dirasakan sangat mendesak mengingat pentingnya kemampuan ini dimiliki oleh peserta didik, khususnya pada Sekolah Menengah Pertama atau Madrasah Tsanawiyah. Namun, sebagian besar peserta didik belum memiliki kemampuan membaca pemahaman sebagaimana yang diharapkan. Standar Isi SMP/MTs menargetkan bahwa pembelajaran bahasa Inggris di jenjang tersebut agar peserta didik dapat mencapai tingkat functional yakniberkomunikasisecara lisan dan tulis untuk menyelesaikan masalah sehari-hari (Well dalam Badan Standar
Nasional Pendidikan, (2003:277). Masalah sehari-hari menyangkut kemampuan peserta didik menggunakan bahasa Inggris sebagai alat komunikasi lisan, seperti berdialog dan monolog. Selain itu, kemampuan berbahasa Inggris untuk membaca wacana pendek dan sederhana, seperti surat kabar. Namun, pada faktanya kemampuan peserta didik tersebut pada umumnya belum memenuhi target itu. Hamra \& Syatriana $(2015: 28)$ mengatakan bahwa banyak hasil penelitian yang menunjukkan bahwa kemampuan membaca pemahaman bahasa Inggris yang dimiliki oleh peserta didik di Indonesia sangat rendah.

Persoalan ini terjadi pula di sebuah sekolah yang berada di Kabupaten Siak Sri Indrapura, yakni SMP Negeri 1 Minas. Hasil wawancara dengan guru bahasa Inggris kelas VIII (Bapak Riko Alfian, S.Pd) diperoleh data bahwa kemampuan membaca pemahaman sebagian besar peserta didik termasuk kategori rendah meskipun ada beberapa orang peserta didik berkemampuan baik. Rendahnya kemampuan mereka bisa diketahui melalui nilai-nilai ulangan harian, ujian tengah semester dan ujian akhir semester. Ketiga jenis pengukuran ini dijadikan acuan untuk melihat kemampuan mereka karena pengukuran ini didominasi oleh tes membaca pemahaman. Dia mengatakan bahwa hasil belajar pada saat ulangan harian menunjukkan bahwa kurang dari $40 \%$ di antara peserta didik yang langsung berhasil memperoleh nilai di atas Kriteria Ketuntasan Minimum (KKM). Sisanya harus diberikan remedial beberapa kali. Hasil analisis tes memperlihatkan bahwa para peserta didik mengalami kesulitan dalam beberapa hal, seperti menentukan gagasan utama paragraf, mengidentifikasi hubungan sebab akibat, menyimpulkan isi wacana dan menentukan informasi tersirat.

Peningkatan hasil belajar peserta didik sangat dipengaruhi oleh model pembelajaran yang dipilih oleh guru. Guru seharusnya mampu memilih dan menerapkan model yang mampu memberdayakan peserta didik dalam 
suatu proses pembelajaran. Salah satu model pembelajaran yang sering diimplementasikan di dalam kelas adalah cooperative learning. Salah satu tipe yang ingin diterapkan dalam penelitian ini adalah model pembelajaran cooperative learning tipe STAD (Student Teams-Achievement Divisions).

Karakteristik STAD dikemukakan oleh Slavin dalam Jolliffe (2013:48) adalah: 1) tim biasanya terdiri atas empat orang yang digabungkan berdasarkan jenis kelamin, kemampuan dan etnik yang berbeda; 2) guru mempresentasikan materi pembelajaran dan peserta didik belajar dalam kelompoknya untuk meyakinkan bahwa semua anggota telah mencapai tujuan pembelajaran; 3) peserta didik mendapat kuis berkaitan dengan materi pembelajaran saat itu; 4) penilaian dirata-ratakan untuk setiap tim dan dibandingkan dengan skor terdahulu; 5) tim yang mencapai kriteria tertentu diberi penghargaan.

Alasan di atas didukung pula oleh beberapa penelitian terdahulu yang relevan. Pertama, Nur'aeni (2013:58) meneliti upaya peningkatan kemampuan membaca peserta didik kelas VIII dengan menggunakan metode STAD di SMP Negeri 17 Tangerang Selatan. Kedua, keefektifan model pembelajaran STAD dalam pembelajaran memahami wacana juga diteliti oleh Wardiah (2015:30). Ketiga, penelitian yang dilakukan oleh Sophia Fithri Al-Munawwarah (2013: 88) mengenai efektivitas penggunaan model pembelajaran tipe STAD dalam pembelajaran membaca pemahaman pada kelas VIII SMP Negeri I Bandung. Hasil dari ketiga penelitian itu membuktikan bahwa model pembelajaran kooperatif tipe STAD efektif dalam pembelajaran membaca pemahaman. Rasional di atas dan diperkuat dengan hasil temuan yang relevan, mendorong peneliti melakukan studi untuk menguji efektivitas penerapan model pembelajaran cooperative learning tipe STAD dalam meningkatkan kemampuan membaca pemahaman. Penelitian ini dilaksanakan pada kelas VIII di SMPN I Minas Kabupaten Siak tahun pelajaran 2016/2017.

\section{METODE PENELITIAN}

Penelitian ini menggunakan metode penelitian quasi experiment atau eksperimen semu dengan desain kelompok kontrol non-equivalen. Seluruh peserta didik kelas VIII SMPN I Minas sebagai populasi. Pengambilan sampel menggunakan teknik purposive sampling sehingga dipilih kelas VIII-6 sebagai kelas eksperimen dan VIII-7 sebagai kelas kontrol. Proses pembelajaran di kelas eksperimen menerapkan model pembelajaran cooperative learning tipe STAD dan kelas kontrol menerapkan model pembelajaran konvensional. Teknik pengumpulan data berupa tes membaca pemahaman yang didukung oleh angket dan observasi.

Ada enam indikator membaca pemahaman yang akan diukur dalam penelitian ini, yaitu menemukan informasi sederhana, menjawab pertanyaan-pertanyaan spesifik, menentukan gambaran umum, memperoleh rincian atau fakta, menemukan ide utama dalam paragraf dan menentukan urutan atau organisasi dari sebuah wacana tertulis. Kemampuan untuk menemukan informasi sederhana, menjawab pertanyaan spesifik dan memperoleh rincian atau fakta merupakan kemampuan dasar dalam memahami sebuah wacana. Indikatorindikator ini digunakan untuk menjawab pertanyaan who, what, where, when dan why.

Kemudian, kemampuan untuk menentukan gambaran umum adalah kemampuan yang harus dimiliki peserta didik dalam menyimpulkan inti sebuah wacana. Sedangkan kemampuan untuk mendapatkan ide-ide utama adalah kemampuan yang harus dimiliki peserta didik dalam menentukan kalimat inti dalam sebuah paragraf. Selanjutnya, kemampuan menentukan urutan atau organisasi dari sebuah wacana merupakan kemampuan untuk menentukan fungsi sosial (social function), unit-unit teks (generic/shematic structure) dan urutan- 
urutan peristiwa dalam sebuah wacana.

Kegiatan penelitian dilaksanakan melalui tahapan-tahapan berikut. Tahap persiapan meliputi: 1) melakukan studi lapangan dan literatur untuk mencari masalah dan kemungkinan solusi; 2) melakukan studi literatur lebih mendalam tentang model pembelajaran cooperative learning tipe STAD; 3) menyusun perangkat pembelajaran dan instrumen penelitian; 4) melakukan uji coba instrumen penelitian; dan 5) mengolah data hasil ujicoba dan menentukan soal yang digunakan dalam pengambilan data. Tahap pelaksanaan dilakukan dengan 1) memberikan pretes keterampilan membaca pemahaman di kelompok kontrol dan kelompok eksperimen; 2) melaksanakan proses pembelajaran dan setiap pertemuan diukur peningkatan keterampilannya; 3) memberikan postes untuk mengukur hasil pembelajaran secara keseluruhan. Tahap akhir memuat 1) mengolah data yang dihasilkan selama proses penelitian dan menganalisis data tersebut; 2) memberikan kesimpulan berdasarkan hasil pengolahan data; dan 3) memberikan saran-saran terhadap aspek- aspek penelitian yang kurang memadai.

\section{HASIL DAN PEMBAHASAN}

Proses pembelajaran dilaksanakan sebayak tiga kali pertemuan. Peningkatan kemampuan membaca pemahaman di kelas eksperimen pada pertemuan pertama dan kedua diukur dengan tes pertama, pertemuan ketiga diukur dengan tes kedua dan terakhir diberikan postes untuk mengukur keseluruhan kemampuan mulai pertemuan pertama sampai ketiga. Sedangkan peningkatan keterampilan di kelas kontrol hanya diukur dengan pretes dan postes. Nilai rata-rata tes keterampilan membaca pemahaman peserta didik di kelas eksperimen selalu mengalami kenaikan pada setiap pertemuan. Nilai rata-rata pretes sebesar 51,03 meningkat pada tes pertama dengan nilai rata-rata sebesar 57,52 kemudian nilai rata-rata tes kedua sebesar 66,28 dan postes sebesar 74,48. Adapun perbandingan nilai rata-rata pretes, postes, gain mutlak dan gain normal membaca pemahaman peserta didik pada kelas eksperimen dan kontrol ditunjukkan pada gambar 1.

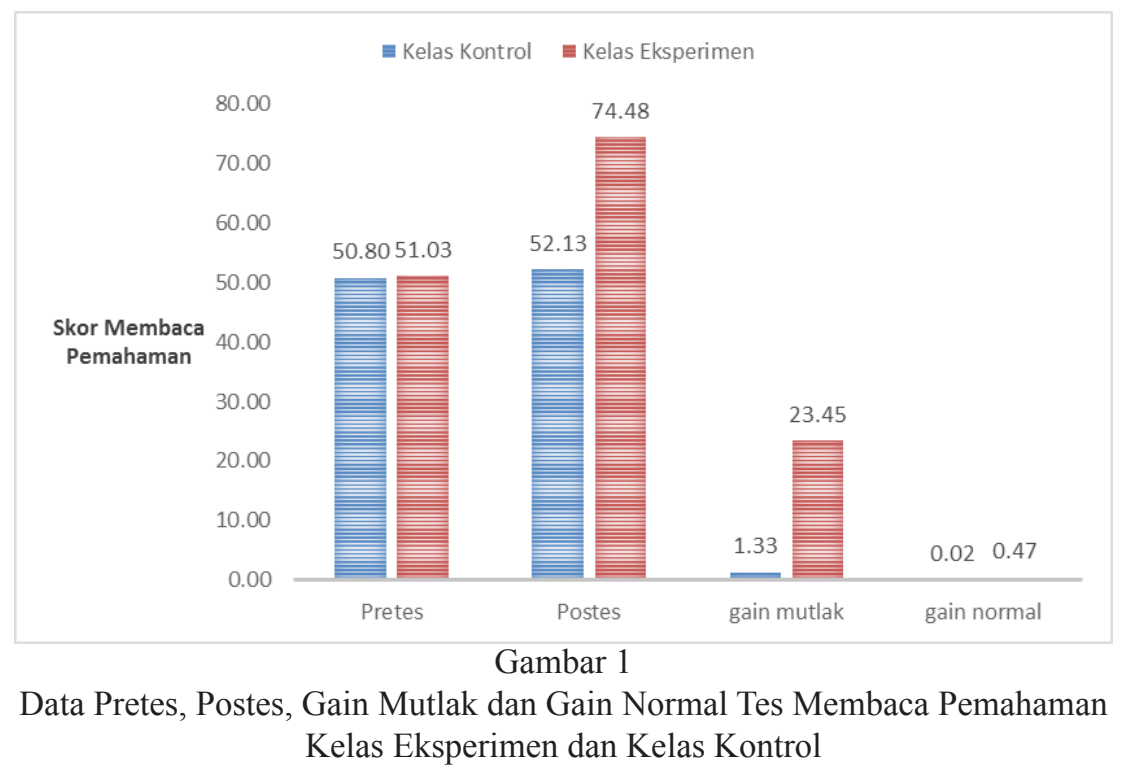

Grafik di atas menunjukkan bahwa nilai rata-rata pretes kelas eksperimen lebih besar dari kelas kontrol ( $\bar{x}_{\text {eksperimen }}=51,03>{ }^{\bar{x}}$ kontrol $=50,80)$. Artinya, kemampuan membaca pemahaman peserta didik sebelum diterapkan STAD lebih baik dari kelas kontrol walaupun tidak besar, yakni perbedaannya sekitar 0.23 poin. Akan tetapi, ada peningkatan lebih baik setelah penerapan STAD, yakni nilai rata-rata postes kelas eksperimen lebih besar 22,35 poin daripada kelas kontrol $\left({ }_{\text {eksperimen }}^{\bar{x}}=74,48\right.$ $>_{\text {kontrol }}=52,13$ ). 
Nilai rara-rata gain mutlak kelas eksperimen sebesar 23,66 dan nilai ratarata gain normal sebesar 0,44. Hal ini menunjukkan kategori sedang. Sedangkan nilai rara-rata gain mutlak kelas kontrol sebesar 1,33 dan nilai rata-rata gain normal sebesar 0,02. Nilai gain normal ini termasuk kategori rendah.

Uji statistik yang diperlukan untuk membuktikan hipotesis yang menyatakan bahwa penerapan model pembelajaran cooperative learning tipe STAD efektif dalam meningkatkan kemampuan membaca

Tabel 1

Hasil Uji Normalitas Data N-Gain Kelas Eksperimen dan Kontrol

\begin{tabular}{llll}
\hline \multicolumn{1}{c}{ Kelas } & Sig. (P-Value) & TingkatSignifikansi $(\alpha)$ & Keterangan \\
\hline Eksperimen & 0,781 & 0,05 & Normal \\
\hline Kontrol & 0,517 & 0,05 & Normal \\
\hline
\end{tabular}

Dengan tingkat kepercayaan 95\% untuk masing-masing kedua kelas tersebut, pada tabel di atas terlihat $p$-value untuk $n$-gain kelas eksperimen adalah $0,781>0,05$, maka dapat disimpulkan data tersebut berdistribusi normal. Sedangkan $p$-value untuk $n$-gain kelas kontrol adalah 0,517>0,05, sehingga dapat disimpulkan bahwa data tersebut

Tabel 2

berdistribusi normal pula. Setelah melakukan uji normalitas, selanjutnya dilakukan uji homogenitas varians skor data $n$-gain kelas eksperimen dan kontrol dengan menggunakan uji Levene. Hasil uji homogenitas data $n$-gain membaca pemahaman kelas eksperimen dan kontrol tampak pada tabel 2.

Hasil Uji Homogenitas Data N-Gain Kelas Eksperimen dan Kontrol

\begin{tabular}{cccc}
\hline \multirow{2}{*}{ Levene Statistic } & P-Value & Tingkat signifikasi $(\alpha)$ & Kesimpulan \\
\cline { 2 - 4 } & 0,964 & 0,05 & Homogen \\
\hline
\end{tabular}

Hasil Uji Levene pada tabel di atas menunjukkan bahwa $p$-value $(0,964)$ lebih besar dari tingkat signifikansi $(0,05)$. Artinya data $n$-gain kelas ekperimen dan kelas kontrol memiliki varians homogen. Perbedaan nilai $n$-gain kelas eksperimen dan kontrol dikatakan signifikan dapat dilihat berdasarkan uji perbedaan data n-gain. Karena uji normalitas dan homogenitas menunjukkan bahwa data menyebar normal dan kedua varians homogen, maka uji hipotesis yang digunakan adalah uji-t dengan dua varians homogen. Adapun hasil uji perbedaan data $n$-gain menggunakan program SPSS 16.0 for Windows tampak pada tabel 3.

Tabel 3

Hasil Uji T Data N-Gain Kelas Eksperimen dan Kelas Kontrol

\begin{tabular}{ccc}
\hline $\mathrm{p}$-value & Tingkat Signifikansi $(\alpha)$ & Kesimpulan \\
\hline 0,000 & 0,05 & $\mathrm{H}_{0}$ ditolak $/ \mathrm{H}_{1}$ diterima \\
\hline
\end{tabular}

Tabel di atas menunjukkan p-value $(0,000)<$ tingkat signifikansi $(0,05)$, maka disimpulkan $\mathrm{H}_{0}$ ditolak dan $\mathrm{H}_{1}$ diterima. Dengan demikian, berdasarkan perhitungan statistik terbukti bahwa terdapat perbedaan yang signifikan antara skor tes membaca pemahaman kelas eksperimen dan kelas kontrol. Dengan kata lain, penerapan model pembelajaran cooperative learning tipe STAD secara signifikan dapat meningkatkan 
kemampuan membaca pemahaman bahasa Inggrispeserta didik.

Hasil pengolahan angket tentang respon peserta didik terhadap model pembelajaran cooperativelearning tipe STAD menunjukkan bahwa peserta didik memberikan respon positif terhadap model pembelajaran ini, yakni sebesar $84 \%$. Rata-rata keseluruhan sebesar 4,18 menunjukkan tanda bahwa peserta didik setuju untuk diterapkan model STAD. Sikap setuju merupakan salah satu bentuk respon positif dari pilihan yang ditawarkan (Sangat Setuju, Setuju, RaguRagu, Tidak Setuju dan Sangat Tidak Setuju).

Deskripsi hasil observasi diambil berdasarkan pedoman observasi memuat 10 kegiatan pembelajaran yang mana dapat dikelompokkan menjadi 5 kategori menurut Robert E Slavin (2013:147-160). Hasil observasi menunjukkan bahwa model STAD itu dapat meningkatkan kemampuan membaca pemahaman bahasa Inggris peserta didik. Hal ini dibuktikan dengan 76\% peserta didik mampu mengikuti implementasi model STAD dengan data kuantitatif yang menunjukkan nilai kelas eksperimen lebih baik dari kelas kontrol.

Berikut ini deskripsi penerapan model pembelajaran Cooperative Learning tipe STAD berdasarkan lima langkah proses pembelajaran menurut Robert E Slavin (2013:147-160). Pada tahap persiapan, kelas eksperimen sudah diajak untuk lebih aktif dalam pembelajaran seperti pembentukan kelompok belajar. Sedangkan di kelas kontrol hanya menyimak tujuan pembelajaran yang disampaikan guru. Dengan kata lain, guru di kelas eksperimen lebih memperhatikan aspek lingkungan membaca sebelum kegiatan inti pembelajaran diberlangsungkan. Lingkungan tersebut meliputi persiapan guru sebelum, pada saat atau setelah pelajaran membaca guna menolong peserta didik memahami teks, cara peserta didik menanggapi tugas, dan suasana umum penyelesaian tugas (hambatan dan dorongan dalam membaca).

Pada tahap presentasi, guru membangkitkan minat peserta didik. Hal tersebut sesuai pendapat Johnson dan Pearson dalam Darmiyati Zuchdi dalam Amna, Azwandi, \& Yunus, (2013:856) yang menyatakan bahwa minat berpengaruh terhadap membaca pemahaman. Minat harus diperhatikan untuk mengetahui seberapa kepedulian pembaca terhadap bacaan yangdihadapinya. Peserta didik berdiskusi untuk menentukan pengalaman paling menarik yang akan dibagi dengan kelompok lain. Sedangkan peserta didik kelas kontrol lebih kaku karena hanya menunggu ditunjuk guru secara acak untuk berbagi pengalamannya. Di samping itu, karena hanya beberapa orang yang ditunjuk untuk bercerita, maka banyak peserta didik lain yang hanya berperan sebagai pendengar (pasif). Ini membuat proses pembelajaran kurang dinamis dan membosankan. Setelah itu, guru menjelaskan konsep-konsep jenis teks recount, seperti social function atau communicative purpose, generic structure atau schematic structure dan language features. Peserta didik diberikan teks yang baru untuk dianalisis generic structurenya dan mereka dilatih mencari ciri-ciri kebahasaan (language features).

Pada tahap Belajar Tim, guru sudah tidak menjelaskan lagi konsep teks recount atau cara belajar tim secara khusus karena peserta didik sudah siap berdiskusi. Hal ini semakin jelas menunjukkan bahwa guru itu cukup sebagai mediator atau pengontrol dalam proses pembelajaran. Sedangkan di kelas kontrol, guru masih menjelaskan tentang teks recount untuk kemudian peserta didik secara kelompok melakukan analisis terhadap teks recount baru.

Pada tahap Kuis, hasil kuis di kelas eksperimen diperiksa dengan cara saling tukar lembar jawaban dengan anggota tim lain. Cara ini akan menstimulus para peserta didik untuk aktif dan kritis terhadap jawaban temannya. Bahkan akan terjadi tukar pemahaman terhadap jawaban yang diberikan oleh guru ketika menemukan 
jawaban temannya yang tidak persis dengan jawaban dari guru hingga mereka (pemeriksa) memutuskan apakah jawaban temannya itu benar atau salah. Pada kondisi seperti ini, dinamika pembelajaran akan semakin terlihat dan menarik.

Pada tahap Rekognisi yang merupakan penutup proses pembelajaran, yang paling menonjol di kelas eksperimen adalah adanya penghargaan atas pencapaian setiap tim berupa sertifikat. Sebuah penghargaan akan memacu semangat peserta didik walaupun hanya berupa tepuk tangan atau ajungan jempol sebagai tanda apresiasi terhadap prestasi belajarnya. Dengan penghargaan ini pula dimungkinkan para peserta didik semakin kuat memiliki jiwa kompetitif positif dalam proses pembelajaran.

Peningkatan kemampuan membaca pemahaman yang telah diuraikan di atas tidak terlepas dari faktor-faktor yang mempengaruhinya. Terdapat dua faktor yang mempengaruhi membaca pemahaman, yaitu faktor internal dan eksternal. Faktor internal berkaitan dengan variabel pembaca, yakni para peserta didik. Faktor ini berkaitan dengan latar belakang pengetahuan, kemampuan kognitif, serta karakteristik afektif pembaca. Sedangkan faktor eksternal meliputi variabel teks, konteks dan penulis (Sadeghi, 2013:199).

\section{SIMPULAN}

Berdasarkan data dan analisis hasil penelitian yang telah dilakukan dapat disimpulkan beberapa poin sebagai berikut: Pertama, proses pembelajaran yang digunakan dalam pembelajaran bahasa Inggris sebelum penelitian ini dilakukan menggunakan metode three-phase technique, yakni pre-reading, while reading dan post reading. Metode ini kurang melibatkan peserta didik dalam pembelajaran secara aktif, mereka kurang diberi kesempatan untuk mencari solusi sendiri atau berdiskusi dengan temannya, melainkan guru banyak menjelaskan atau mencontohkan materi pembelajaran. Hal ini berdampak pada rendahnya kemampuan membaca pemahaman peserta didik dalam pembelajaran bahasa Inggris.

Kedua, model pembelajaran cooperative learning tipe STAD terbukti efektif dapat meningkatkan kemampuan membaca pemahaman peserta didik. STAD meliputi lima tahapan dalam pembelajaran, yaitu presentasi kelas yang dilaksanakan oleh guru, kerja tim atau diskusi kelompok, kuis individu, penskoran hasil kuis individu yang dijadikan skor kemajuan tim dan penghargaan terhadap tim. Kelima tahapan ini merupakan inti dari model pembelajaran cooperative learning tipe STAD yang membedakan dengan diskusi-diskusi yang sudah biasa dilakukan di kelas.

\section{REKOMENDASI}

Pertama, model pembelajaran yang lebih mengedepankan kerja tim ini masih jarang diterapkan. Dengan demikian, semakin sering diterapkan, maka peserta didik akan semakin mudah menyesuaikan diri dalam kelompok dan terbebas dari "ketergantungan" pada gaya belajar individualistis. Ini menjadi tantangan tersendiri bagi guru bahasa Inggris.

Kedua, minimnya penguasaan kosa kata masih menjadi kendala bagi peserta didik. Patut diduga bahwa ini disebabkan oleh jarangnya frekuensi peserta didik untuk mempraktikan bahasa Inggris dan materi pembelajaran cenderung teoritis. Ketiga, masihkurangnyamediapembelajaranmenjadi tugas pimpinan sekolah beserta jajarannya (guru dan orangtua) untuk menyediakannya, baik dengan dana dari orang tua melalui kesepakatan yang adil, maupun melalui pengajuan kepada pemerintah, terutama media pembelajaran audio visual yang akan membuat proses pembelajaran lebih atraktif. 


\section{DAFTAR RUJUKAN}

Amna, P., Azwandi, Y., \& Yunus, M. (2013). Meningkatkan Kemampuan Membaca Pemahaman Pada Siswa Tunarungu Dengan Menggunakan Teknik Skimming. Jurnal Ilmiah Pendidikan Khusus, 854-862.

Badan Standar Nasional Pendidikan. (2003). Standar Isi Untuk Satuan Pendidikan Dasar Dan Menengah. Jakarta: Badan Standar Nasional Pendidikan.

Caldwell, J. (JoAnne S. (2016). Comprehension assessment : a classroom guide. New York: Guilford Press.

Hamra, A., \& Syatriana, E. (2015). Developing A Model Of Teaching Reading Comprehension For Efl Students. TEFLIN Journal, 21(1), 27-40.

Jeffries, L., Mikulecky, B. S., \& Mikulecky, B. S. (2012). Basic reading power 1 : extensive reading, vocabulary building, comprehension skills, thinking skills. USA: Pearson Longman.

Jolliffe, W. (2013). Cooperative learning in the classroom : putting it into practice. London, United Kingdom: Paul Chapman Pub.

Lems, K., Miller, L. D., \& Soro, T. M. (2014). Teaching reading to English language learners : insights from linguistics. New York: The Guilford Press.

NUR'AENI. (2013). Developmen students reading ability by using student team achievement division (STAD) teachnique: a classroom action reseach in the yer of VII-6 clas of SMPN 17 Tangerang Selatan. UIN Syarif Hidayatulloh.

Qismullah Yusuf, Y., Natsir, Y., \& Hanum BEd, L. (2015). A Teacher's Experience in Teaching with Student TeamsAchievement Division (STAD) Technique. International Journal of Instruction July, 8(2), 1694-609.

Robert E Slavin. (2013). Cooperative learning (teori, riset dan praktik). Bandung: Nusa Media.

Sadeghi, K. (2013). The Key for Successful Reader-writer Interaction: Factors Affecting Reading Comprehension in L2 Revisited | Asian EFL Journal. Asian EFL Journal, 9(3), 198-220.

Sophia Fithri Al-Munawwarah. (2013). The Implementation OfCooperative Learning: Student Teams-Achievement Divisions Technique In Teaching Reading Comprehension (A Case Study in A class of Eight Grade Students at One Public School in Bandung). Journal of English and Education, 1(2), 82-89.

Wardiah, D. (2015). Keefektifan Model Pembelajaran Stad (Student Team Achievement Division) Dalam Memahami Wacana Siswa Kelas Viii Smp Tridarma Palembang. Wahana Didaktika, 12(3), 30-42. 